\title{
Smart Teens with Reproductive Health Digital Pocket Book
}

\author{
Rosidah Solihah, Neli Sunarni, Sri Utami Asmarani \\ STIKes Muhammadiyah Ciamis, Ciamis, Indonesia \\ a)Corresponding author: rosidahsolihah/@gmail.com
}

\begin{abstract}
Adolescents are one of the population groups that are quickly influencing by negative and positive information flows. Adolescent problems related to reproductive health often stem from a lack of information, understanding and awareness to achieve reproductive health. The importance of knowledge about reproductive health will help adolescents make decisions whether they will take healthy or unhealthy actions against themselves. Efforts to create healthy adolescents are to disseminate information through an application, namely an android-based digital pocketbook on reproductive health. This community service activity aims to provide education to adolescents and increase adolescent knowledge about reproductive health. The method used in this educational activity is through three stages, firstly giving a questionnaire as a pretest, secondly, providing education about reproductive health, and thirdly giving a post-test questionnaire. This activity increases adolescent knowledge about reproductive health seen from the pretest and post-test results. In conclusion, teenagers already understand reproductive health.

Keywords: Adolescents, digital pocket book, reproductive health.
\end{abstract}

\section{INTRODUCTION}

Adolescents are one of the population groups which are quickly influencing by the flow of information, both negative and positive. The information received most rapidly and has a lot of influence is through print media such as magazines, newspapers, tabloids, and electronic media such as radio, television, and the internet. As research conducted by 'HEART' FKM UNHAS in 2009 on 2,135 UNHAS students showed that access to pornographic media was 314 people (15\%) via CD/DVD, 283 people (13\%) via cellphone, 535 people (25\%) via the internet, 55 people (3\%) through magazines and the rest through other media ("HEART" FKM UNHAS, 2009).

Adolescent problems related to reproductive health, often stem from a lack of information, understanding, and awareness to achieve reproductive health. One of the causes is the negative effect of the development of science and technology, especially social media which is very fast and easily accessible by all parties. In some areas, many teenagers do not get enough and correct information about sexuality and reproductive health. This is because there is an opinion that putting the brakes on information, will prevent teenagers from unwanted sexual behavior. Most of the sexually active adolescents, both married and unmarried at the age of fewer than 20 years, many of whom have not been touched with reproductive health services (including contraceptive services), prevention and treatment of STIs or HIVIAIDS as well as pregnancy and childbirth care, factors that hinder it can be geographical, economic and psychological. (Representative of the West Java BKKBN, 2011).

Based on this explanation, special attention is needed to overcome the problems among adolescents so that adolescents are mentally healthy. Knowledge about the importance of knowing at least reproductive health can help adolescents decide whether they will take healthy or unhealthy actions against themselves, especially those related to reproductive health (Intan Kumalasari, 2012).

Efforts to create healthy adolescents are to disseminate information or knowledge about health reproduction through social media by creating a digital pocketbook on android-based 
reproductive health. With correct information about reproductive health, it is hoped that adolescents will have a responsible attitude and behaviour regarding the reproductive process.

\section{MATERIALS AND METHODS}

The method used in this community service activity is an educational method through three stages, namely first doing a pretest using a previously prepared questionnaire, secondly providing education by first introducing the reproductive health digital pocketbook application, third doing a posttest using a questionnaire that was filled out directly by the activity participants. This activity was carried out at the Integrated Middle School Ishlahul Mubtadiin Sumberjaya, Cihaurbeuti, Ciamis. Participants who attended were students or teenagers, totalling 41 people. The tools used in this activity are leaflets, power points, and digital pocketbooks on reproductive health.

\section{RESULTS}

The analysis is used to determine the increase in adolescent knowledge about reproductive health in adolescents. The instrument used is a questionnaire. The completed questionnaire was analyzed with the results showing the average value of the pretest was 67 while the average value of the posttest was 83 . So there was an increase in the value of adolescent knowledge after being given education.

\section{DISCUSSION}

Reproductive health is a state of complete physical, mental and social health, not merely free from disease or disability related to reproductive functions and processes. (WHO, 2014) An understanding of reproductive health is essential needed by adolescents to add information for them. This information was obtained from the education provided in community service activities. These activities were evaluated by distributing questionnaires before and after the teaching was conducted. The results of the evaluation can have to be seen in table 1.

Based on the evaluation results, it shows that there is an increase in adolescent knowledge about reproductive health seen from the average value before and after education is carried out. These results are in line with the results of several community service activities, which state an increase in adolescent knowledge about reproductive health (Ira Marti Ayu, Decy Situngkir, Mayumi Nitami, 2020; Na'mah et al., 2019).

The education provided to adolescents aims to create healthy adolescents. This education uses tools or media in the form of an Android-based digital pocketbook on reproductive health, making it easier for participants to access information. This is in line with research conducted by Neli Sunarni et al., who stated that the android-based reproductive health digital pocketbook application helps adolescents obtain information about reproductive health (Sunarni et al., 2020). The digital pocketbook is designed with materials in it in the form of materials and videos on adolescent reproductive health. The five senses channel the most to the brain are the eyes (approximately $75 \%$ to $87 \%$ ). In contrast, $13-25 \%$ of human knowledge is obtained or conducted through other senses, so that the more five senses are used, the more precise the knowledge acquired (Ircham Mahfoedz, 2009). Audiovisual is one of the media that presents information or messages through hearing and seeing. Media as props are used in order or aim to facilitate the delivery of messages. Teaching aids are arranged based on the principle that knowledge that exists in humans is received or captured through the five senses (Hikmawati, 2011).

Increasing adolescent knowledge about reproductive health can be interpreted that adolescents understand and understand the material that has been delivered. This understanding can be seen during the discussion; participants can re-explain the material that has been provided. This is in line with the results of community service conducted by Dewi Susilawati et al., which showed that $80 \%$ of participants could re-explain the definition of 
reproductive health, how to maintain reproductive organs, reproductive organ infections, and HIVIAIDS (Dewi Susilawati, Nur Fadji Nilakesuma, 2019). Dian Permatasari carried out community service so that activity participants could understand the importance of maintaining reproductive health and supporting reproductive health (Permatasari, 2021).

\section{CONCLUSIONS AND RECOMMENDATIONS}

Community service activities regarding adolescent reproductive health received a good response from the Ishlahul Mubtadiin Integrated Junior High School managers and the activity participants because it is essential so that adolescents' understanding of reproductive health increases. This understanding can be seen from the increase in the average value of adolescent knowledge about reproductive health. The suggestions for participants are to maintain the results of experience that have been obtained by reading more other sources, especially about reproductive health and the management not only cooperates with the education side but also with the local health centre.

\section{ACKNOWLEDGMENTS}

The authors express their deepest gratitude to those who have assisted in this community service activity, namely STIKes Muhammadiyah Ciamis through the Institute for Research and Community Service (LPPM) and to the managers and participants of the Ishlahul Mubtadiin Integrated Junior High School. They are willing to become partners in this activity.

\section{REFERENCES}

Dewi Susilawati, Nur Fadjri Nilakesuma, D. O. S. (2019). Penyuluhan Kesehatan Reproduksi Remaja Di Smp Pertiwi Siteba Padang. Penyuluhan Kesehatan Reproduksi Remaja, 2, 166170.

Dian Permatasari, E. S. (2021). Pendidikan Kesehatan Reproduksi Pada Remaja. Jurnal Empathy, 2(1), 8-12.

"HEART" FKM UNHAS. (2009). Perilaku Seksual Mahasiswa UNHAS Maksar, disampaikan padaTemu Nasional Kesehatan Seksual Mahasiswa: Saatnya Peduli dan Membuat Perubahan.

Hikmawati, I. (2011). Promosi Kesehatan Untuk Kebidanan. Numed.

Intan Kumalasari, I. A. (2012). Kesehatan Reproduksi Untuk Mahasiswa Kebidanan dan Keperawatan. Salemba Medika.

Ira Marti Ayu, Decy Situngkir, Mayumi Nitami, N. (2020). Program peningkatan pengetahuan kesehatan reproduksi remaja di SMK “ $X$ ” Tangerang Raya. 3(April), 87-95.

Ircham Mahfoedz, E. S. (2009). Pendidikan Kesehatan Bagian Dari Promosi Kesehatan. Fitramaya.

Na'mah, L. U., Zakiyyah, N., Khasanah, E. W., Hermawan, H., \& Setiawan, A. (2019). Peningkatan pengetahuan melalui sosialisasi kesehatan reproduksi remaja tentang kenakalan remaja ( narkoba dan HIV/AIDS). The 8th University Research Colloquium 2018 Universitas Muhammadiyah Purwokerto PENINGKATAN, Proceeding of The 8th University Research Colloquium 2018: Bidang MIPA dan Kesehatan, 263-266.

Perwakilan BKKBN Jawa Barat. (2011). Penyiapan Kehidupan Berkeluarga Bagi Remaja Bandung.

Sunarni, N., Solihah, R., \& Purwati, A. E. (2020). Rancang bangun buku saku digital kesehatan reproduksi berbasis android dalam pendidikan kesehatan. Jurnal Riset Kebidanan Indonesia, 4(2), 26-31. https://doi.org/10.32536/jrki.v4i2.90

WHO. (2014). Reproductive Health. World Health Organization. 


\section{APPENDIX}

Table 1. Pre and Post-test Assessment

\begin{tabular}{ccc}
\hline No. & Pretest & Posttest \\
\hline 1. & Average $=67$ & Average $=83$ \\
2. & Highest $=76$ & Highest $=96$ \\
3. & Lowest $=52$ & Lowest $=68$
\end{tabular}
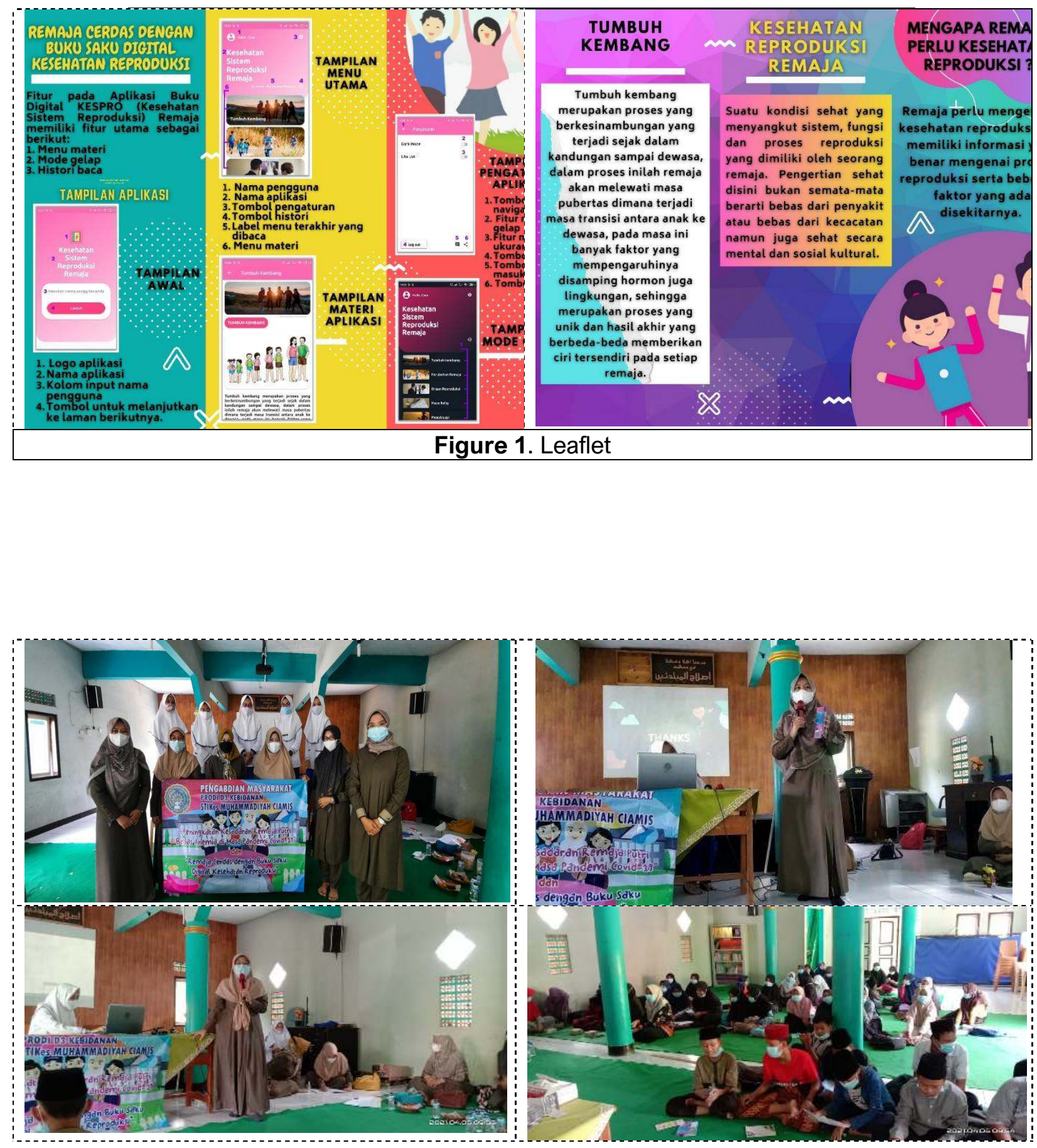


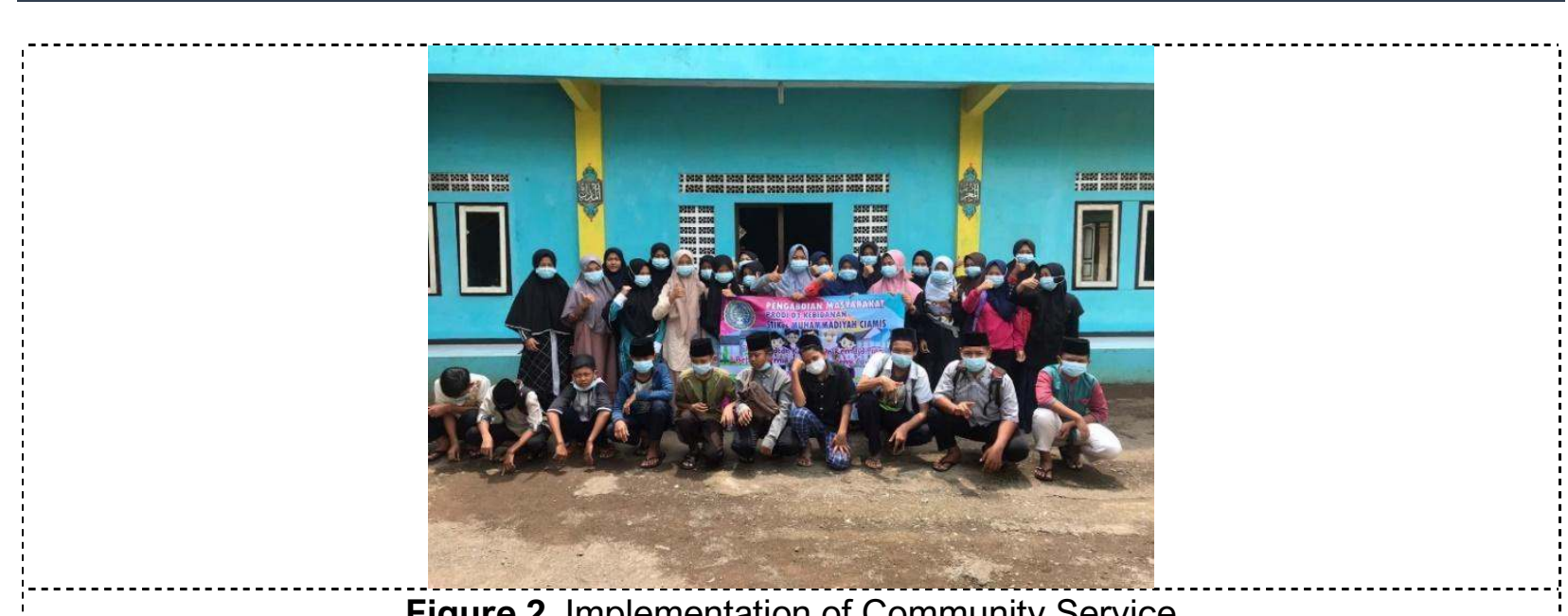

Figure 2. Implementation of Community Service 